\title{
Reaction of lime trees (Tilia sp.) growing along the Żwirki i Wigury Street in Warsaw on soil salinity caused by chemical technology of snow removal
}

\author{
Wojciech Kwasowski, Monika Czyż \\ Division of Soil Science, Department of Soil Environment Science, \\ Warsaw University of Life Sciences, 159 Nowoursynowska 159, 02-776 Warsaw, Poland \\ e-mail: wojciech_kwasowski@sggw.pl
}

\begin{abstract}
Summary. The studies were focused on the influence of sodium chloride application in the chemical technology of snow removal from streets on the conditions of lime trees (Tilia sp.) growing along the Żwirki i Wigury Street in Warsaw and the determination of the degree of salinity on soils under street vegetation. The analyses show that chemical technology of soil removal causes changes in the soil environment. They include ionic imbalance of the soil solution and change of soil reaction. Electrical conductivity of the saturated soil extract also increases, as well as content of soluble salts in soils under street vegetation. Sodium chloride significantly influences the lime trees growing along the Żwirki i Wigury Street. Leaves growing directly near the street show severe effects of paralysis by sodium chloride in form of necrosis, discoloration (browning), and in consequence drying and premature leaf-fall.
\end{abstract}

Key words: soil salinity, sodium chloride, lime tree.

\section{Introduction}

Intense development of municipal transportation requires correct maintenance of streets in all climatic conditions throughout the year. The most commonly applied method of road slipperiness removal is chemical technology based mainly on the application of sodium chloride. This method has negative influence of the physicochemical properties of soils as well as direct and indirect influence on street vegetation.

The study is focused on the analysis of the influence of chemical technology of snow removal on the condition of lime trees (Tilia sp.) in the Żwirki i Wigury Street in Warsaw and evaluation of the salinity conditions of soils.

\section{Study area}

Based on the observation of the condition of lime trees carried out from early spring, four measurement points were established. They were situated along the main crossways of the street. The trees growing along the crossways showed distinct signs of growth disorders, such as leaf necrosis, premature fall and drying up of particular branches and trunks. Each selected point was located $2 \mathrm{~m}$ from the street margin and ca. $2 \mathrm{~m}$ from the nearest tree. The control point that was not subject to the salination processes was localized in a nearby park. 


\section{Study method}

Soil profiles were drilled with an auger in measurement points (profiles nos. 1-4) and a control point (profile no. 0); soil samples were collected from each profile from the following depth intervals: $0-30 ; 30-60 ; 60-90$ and $90-120 \mathrm{~cm}$. The soil samples were dried and disintegrated in a mortar. The grain size composition was determined using the Casagrande metod in the modification of Prószyński, $\mathrm{pH}$ was tested in $1 \mathrm{M} \mathrm{KCl}$, electrical conductivity of the soil saturated extract was measured conductometrically. Water extracts from soils were made in a 1:5 proportion of soil to water. Ions of soluble salts of $\mathrm{Ca}, \mathrm{Mg}$, $\mathrm{K}$ and $\mathrm{Na}$ were determined in the extracts using the AAS method, chlorides were determined argentometrically; sulphates - nephelometrically and bicarbonates - acidimetrically. The total content of soluble salts was calculated as the sum of particular ions in the water extract.

Table 1. Characteristics of soil salinity

\begin{tabular}{|c|c|c|c|c|c|}
\hline \multirow{2}{*}{$\begin{array}{c}\text { Profile } \\
\text { No. }\end{array}$} & \multirow{2}{*}{$\begin{array}{c}\text { Depth } \\
{[\mathrm{cm}]}\end{array}$} & \multirow{2}{*}{$\begin{array}{c}\mathbf{p H} \\
{[\text { in } 1 \mathrm{M}} \\
\mathrm{KCl}]\end{array}$} & \multirow{2}{*}{$\begin{array}{c}\mathrm{EC}_{\mathrm{e}} \\
{\left[\mathrm{dS} \cdot \mathbf{m}^{-1}\right]}\end{array}$} & $\mathrm{Cl}^{-}$ & $\begin{array}{c}\text { Soluble } \\
\text { salts }\end{array}$ \\
\hline & & & & \multicolumn{2}{|c|}{ [mg-100 $\mathrm{g}^{-1}$ of soil] } \\
\hline \multirow{4}{*}{1} & $0-30$ & 7.1 & 2.7 & 36.2 & 172 \\
\hline & $30-60$ & 7.2 & 3.3 & 39.1 & 171 \\
\hline & $60-90$ & 6.8 & 3.8 & 51.8 & 206 \\
\hline & $90-120$ & 6.9 & 2.9 & 40.5 & 189 \\
\hline \multirow{4}{*}{2} & $0-30$ & 6.9 & 2.4 & 27.7 & 124 \\
\hline & $30-60$ & 7.3 & 4.1 & 55.3 & 209 \\
\hline & 60-90 & 6.8 & 2.9 & 55.4 & 184 \\
\hline & 90-120 & 6.9 & 2.1 & 33.4 & 143 \\
\hline \multirow{4}{*}{3} & $0-30$ & 6.9 & 3.0 & 38.0 & 154 \\
\hline & $30-60$ & 7.1 & 4.6 & 58.9 & 224 \\
\hline & $60-90$ & 7.3 & 5.4 & 68.9 & 257 \\
\hline & 90-120 & 7.2 & 5.9 & 66.0 & 256 \\
\hline \multirow{4}{*}{4} & $0-30$ & 6.9 & 2.0 & 36.4 & 133 \\
\hline & $30-60$ & 7.0 & 3.8 & 42.6 & 180 \\
\hline & $60-90$ & 7.0 & 4.6 & 65.3 & 235 \\
\hline & $90-120$ & 7.2 & 5.4 & 68.9 & 249 \\
\hline \multirow{4}{*}{0} & $0-30$ & 6.6 & 0.7 & 2.1 & 65.4 \\
\hline & $30-60$ & 6.7 & 0.8 & 2.1 & 70.2 \\
\hline & $60-90$ & 6.7 & 0.7 & 1.4 & 54.3 \\
\hline & 90-120 & 6.7 & 0.7 & 1.4 & 45.8 \\
\hline
\end{tabular}

Five samples of leaves from each tree were collected from the lime trees growing near the profiles; they were dried in air temperature, later at $60^{\circ} \mathrm{C}$, and then ground. Finally, four collective samples were obtained from leaves of lime trees growing near profiles 1-4; an additional collective sample represented the control point. The content of ash particles: $\mathrm{Ca}, \mathrm{Mg}, \mathrm{Na}$ and $\mathrm{K}$ was established in the leaf material using the AAS method; chlorides were determined argentometrically.

\section{Results and discussion}

The surface horizons of the studied soils were developed from loamy sands, whereas deeper in the profiles occurred clayey silt or slightly clayey silt. The reaction of the studied soils was neutral or alkaline and varied within 6.7 to 7.3 (Tab. 1).

Soil salinity can be characterized based on electrical conductivity of saturated soil extracts, the quantity of the chloride anion and the sum of soluble soils in the soil solution. Many authors (Pokojska et al. 1998; Pracz \& Kwasowski 2005; Hulisz 2007) suggest that the boundary value of electrical conductivity of saturated soil extracts, above which the soils are considered as salinated should be $2 \mathrm{dS} \cdot \mathrm{m}^{-1}$. This means that all studied soils are salinated, which is also confirmed by the content of soluble soils usually exceeding $0.2 \%$.

In non-saline soils, the content of the chloride ion is low and most commonly does not exceed $3 \mathrm{mg} \cdot 100 \mathrm{~g}^{-1}$ of soil. The content of this ion exceeding $10 \mathrm{mg} \cdot 100 \mathrm{~g}^{-1}$ of soil may unfavourably influence plant growth (Czerwiński et al. 1984; Kwasowski 1996). In soils under the analyzed street vegetation, the content of the chloride ion was elevated and several times exceeded the contents typical of non-saline soils.

The ionic composition of soluble salts in the soils under street vegetation varied from the ionic composition typical of soils. Application of sodium chloride in the winter season caused significant changes in the quantitative series of ions in the soil solutions. In non-saline soils, the decreasing series of ion content in chemically comparable quantities are:

- for cations: $\mathrm{Ca}^{2+}>\mathrm{Mg}^{2+}>\mathrm{K}^{+}>\mathrm{Na}^{+}$,

- for anions: $\mathrm{HCO}_{3}{ }^{-}>\mathrm{SO}_{4}{ }^{2-}>\mathrm{Cl}^{-}$.

Such series were also determined in the soil of the control point (profile 0), whereas in soils collected along the Żwirki i Wigury Street (profiles 1-4) the ion series were:

- for cations: $\mathrm{Na}^{+}>\mathrm{Ca}^{2+}>\mathrm{Mg}^{2+}>\mathrm{K}^{+}$, or $\mathrm{Ca}^{2+}>\mathrm{Na}^{+}>$ $\mathrm{Mg}^{2+}>\mathrm{K}^{+}$

- for anions: $\mathrm{Cl}^{-}>\mathrm{HCO}_{3}^{-}>\mathrm{SO}_{4}{ }^{2}$. These results are similar to those from other reports (Czerwiński et al. 1984; Dużyński \& Kusza 1999; Pracz 2001) and indicate salination of the studied soils by sodium chloride. 


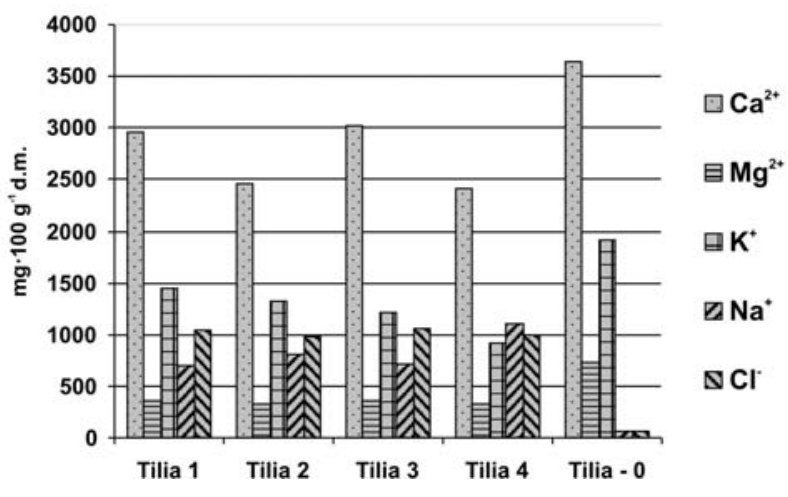

Figure 1. Content of ions in the lime tree leaves

The first observed symptom indicating leaf paralysis by sodium chloride was the appearance of yellowing of the leaf tip by the end of May. Increase of the content of chloride ions in the leaves caused browning of the leaves, followed by drying that covered successively larger parts of the leaf blade. A characteristic feature of paralysis symptoms was a yellow zone located between the external part of the blade covered by necrosis and the internal, healthy part of the leaf. In mid-July most leaves were completely dry, and in August light-green, young leaves appeared on some branches. Similar symptoms, as a reaction of trees to salination, were noted by other authors (Dużyński \& Kusza 1999; Brogowski et al. 2000).

The analyzed leaves of lime trees were characterized by a disordered ionic composition, particularly in relation to the content of $\mathrm{Na}^{+}$and $\mathrm{Cl}^{-}$ions in relation to the lime trees from the control point (Fig. 1).

The content of chlorine varied from 988 to $1058 \mathrm{mg} 100 \mathrm{~g}^{-1} \mathrm{~d}$.m. of leaves, which over a dozen times exceeded the content of this ion in lime leaves growing in the park. The ratio of bivalent to univalent cations was much lower; this is linked with the accumulation of excessive amounts of sodium ions in the leaves. Brogowski et al. [2000] noted exceeded contents of sodium and chlorine ions in lime leaves growing along the streets in Łódź, as well as the narrow ratio of bi- to univalent cations, a fact that is considered an important cause of pathological changes in leaves.

\section{References}

Brogowski Z., Zagórski Z., Czarnowska K., Chojnicki J. \& Pracz J., 2000, Wpływ stresu solnego na stan chemiczny liści drzew z terenu miasta Lodzi [Influence of salt stress on the chemical composition of tree leaves from the Łodź city area], Rocz. Glebozn. 51 (1/2): 17-28.

Czerwiński Z., Pracz J. \& Piątek A., 1984, Wpływ odpadów z Janikowskich Zakładów Sodowych na tereny rolnicze [Influence of wastes from the Janowo Soda Works on agricultural areas], Rocz. Glebozn. 35 (3/4): 87-105.

Dużyński M. \& Kusza G., 1999, Wpływ środków chemicznych stosowanych do odśnieżania na roślinność wysoką Opola [Influence of chemical compounds applied in snow removal on higher plants of the Opole town], Zesz. Prob. Post. Nauk Rol. 467, II: 635-640.

Hulisz P., 2007, Propozycje systematyki gleb zasolonych występujących w Polsce [Proposal of systematics of Polish salt-affected soils], Rocz. Glebozn. 58 (1/2): 121-129.

Kwasowski W., 1996, Zasolenie gleb i skład jonowy soli łatwo rozpuszczalnych $\mathrm{w}$ wodzie $\mathrm{w}$ rejonie wpływu Elektrociepłowni Siekierki [Soil salinity and composition of readily soluble salts in soils in the vicinity of the Siekierki Electric Power Plant], Rocz. Glebozn. 47, supl.: 145-152.

Pokojska U., Bednarek R. \& Hulisz P., 1998, Problemy systematyki gleb zasolonych w odniesieniu do obszaru objętego wpływem Inowrocławskich Zakładów Chemicznych „Soda-Mątwy” SA [Taxonomy problems of salt-affected soils with reference to the area influenced by the Inowrocław Chemical Works Soda-Mątwy S.A.], Zesz. Prob. Post. Nauk Rol. 460: 513-521.

Pracz J., 2001, Właściwości naturalnych gleb słonych występujących w pobliżu jeziora Resko Przymorskie [Properties of natural saline soils occurring near the Resko Przymorskie Lake], Rocz. Glebozn. 52 (3/4): 5-16.

Pracz J. \& Kwasowski W., 2001, Charakterystyka zasolenia gleb siarczkowych i kwaśnych siarczanowych w rejonie Mrzeżyna [Salinity of sulphide and sulphate soils in the Mrzeżyno area], Rocz. Glebozn. 52 (3/4): $17-31$. 